\title{
STUDENTS AND GRADUATES OF THE UNIVERSITY OF SZCZECIN AT THE 32ND OLYMPIC GAMES TOKYO 2020
}

\author{
Jerzy Eider \\ University of Szczecin, Faculty of Health and Physical Culture, Institute of Physical Culture Sciences, Poland \\ ORCID: 0000-0002-8401-6442 | e-mail: jerzy.eider@usz.edu.pl
}

\begin{abstract}
Ahstract So far, in the history of the modern Summer Olympic Games, the event has not been organized only three times - due to World Wars - in 1916 (6th Olympic Games), 1940 (12th Olympic Games), and 1944 (13th Olympic Games). For the first time in its 124-year history, the International Olympic Committee decided (on March 24, 2020) to postpone the Games to the following year due to the pandemic caused by the SARS-CoV-2 virus. The 32nd Olympic Games Tokyo 2020 were held between July 23 and August 8, 2021, in a strict sanitary regime. The purpose of this paper is: to present the academic status of athletes students and graduates of the University of Szczecin - who participated of the Olympic Games Tokyo 2020; to present key sports achievement to-date of these athletes; to analyze the sports results obtained by them in athletics in the context of medals won at the 32nd Olympic Games. The Polish Olympic team who participated in Tokyo 2020 included three athletes (runners), associated with the University of Szczecin: Patryk Dobek - $800 \mathrm{~m}$ run, Marcin Lewandowski - 1,500 m run, and Adam Nowicki marathon. The coaching staff of Polish athletes included another graduate of the University of Szczecin, Jacek Kostrzeba. Additionally, Marek Kolbowicz, PhD - an employee of the Institute of Physical Culture Sciences at the Faculty of Health and Physical Culture of the University of Szczecin (INoKF WKFiZ US) - acted as a TV commentator/rowing expert. WKFiZ US' student - Patryk Dobek - won a bronze medal in the $800 \mathrm{~m}$ run, which was an unexpected surprise in the Polish Olympic team.
\end{abstract}

Key Wordls students, graduates, Olympic athletes, Olympic Games, bronze medal, Tokyo 2020, Paralympics, University of Szczecin

\section{Introduction}

The choice of host of the 32nd Olympic Games was announced on September 7, 2013 in Buenos Aires, Argentina, during the 125th Session of the International Olympic Committee (IOC). Among the previously accepted three candidate cities - Madrid (Spain), Istanbul (Turkey), and Tokyo (Japan) - members of the Committee elected the capital of Japan. The date of this largest sports event was also determined: - July 24 - August 9, 2020. It is worth noting that Tokyo already hosted one such event: the 18th Olympic Games.

So far, in the history of the modern Summer Olympic Games, the event has not been organized only three times - due to World Wars - in 1916 (6th Olympic Games), 1940 (12th Olympic Games), and 1944 (13th Olympic Games). However, for the first time in the 124-year history, due to SARS-CoV-2 pandemic, '... and postulates submitted by national committees (including Polish Olympic Committee), the International Olympic Committee decided to postpone the Games to the following year with an approximate time frame of July 23 - August 8, but 
keep the original name 'Tokyo 2020' (Urbaś, 2020, p. 3). The decision of the IOC was consulted with and approved by the Japanese government and the Tokyo 2020 Organizing Committee (www.olimpijski.pl). The postponement of 32nd Olympics and the 16th Paralympics to 2021 significantly increased the financial costs of organizing the events (Banio, 2021a; Jastrząbek, 2021; Omorczyk, 2021; Urbaś, 2021).

The 32nd Olympic Games Tokyo 2020 were held between July 23 and August 8, 2021, in a strict sanitary regime. The participants came from 205 countries, and competed in 33 disciplines (339 competitions). Sports facilities were located in Tokyo and in its immediate vicinity, in the Tokyo Bay and in towns located far from the Japanese capital, e.g. Sapporo (Przegląd Sportowy, 2021).

The purpose of this paper is:

1. To present the characteristics of the academic status of athletes who participated in the 32 Olympic Games Tokyo 2020 - students and graduates of the University of Szczecin.

2. To present key sports achievement to-date of these athletes.

3. To analyze the sports results obtained by them in athletics in the context of medals won at the 32nd Olympic Games.

4. To continue research (sports analyzes and biographical ones) on the participation of these athletes in the Summer Olympic Games - students and graduates (athletes and coaches) of the Pedagogical University in Szczecin, University of Szczecin.

\section{Materials and Methods}

The study group consisted of five people - excellent sports personalities and participants of the Olympic Games, who also performed various functions during the 32nd Olympic Games Tokyo 2020. The group includes three athletes - runners Patryk Dobek, Marcin Lewandowski, and Adam Nowicki - as well as the athletics coach Jacek Kostrzeba, and sports expert in rowing and canoeing, Marek Kolbowicz.

In 2018, Patryk Dobek (Table 1) graduated with a Bachelor's degree in Physical Education from the Faulty of Health and Physical Culture, University of Szczecin (WKFiPZ US). Currently, he is a Master's student (2nd year) in the field of Physical Education at the Faculty of Health and Physical Culture, University of Szczecin (WKFiZ US the current name of the faculty since October 1, 2019). He is a diligent student who skillfully combines professional sports and academic education. He is preparing a Master's thesis on his running competition - men's $800 \mathrm{~m}$ run (the supervisor of his Master's thesis is the author of this article).

Tahle 1. Research material

\begin{tabular}{lccc}
\hline \multicolumn{1}{c}{ First and last name } & Academic status & Function at the Olympic Games & Sports discipline - Olympic competition \\
\hline Patryk Dobek & student & athlete & ATH $^{* *}-800 \mathrm{~m}$ \\
Marcin Lewandowski & graduate & athlete & ATH $-1,500 \mathrm{~m}$ \\
Adam Nowicki & student & athlete & ATH - marathon \\
Jacek Kostrzeba & graduate & coach & ATH $-1,500 \mathrm{~m}^{* * *}$ marathon \\
Marek Kolbowicz & graduate & sports expert & rowing and canoeing \\
\hline
\end{tabular}

*Alphabetic order.

"ATH - athletics.

"* Coach of Michał Rozmys

Source: Documentation (2021); Przegląd Sportowy (2021); Urbaś (2021). 
Patryk Dobek practices athletics; he specializes in $400 \mathrm{~m}$ run, $4 \times 400 \mathrm{~m}$ relay, $400 \mathrm{~m}$ hurdles, and - since 2021 - in $800 \mathrm{~m}$ run. He is a multiple medalist of the World Junior Championships, Junior Championships, Youth European Championships, World Military Sports Games (except $800 \mathrm{~m}$ run). He participated in the 31st Olympic Games in Rio de Janeiro (400 m hurdles) and the 32nd Olympic Games in Tokyo (800 m run). In August 2020 in Bydgoszcz, at the 8th European Athletics Team Championships, Dobek twice obtained a result better than the PZLA's qualifying standard for the Tokyo Olympics in the $400 \mathrm{~m}$ hurdles (48.90) (Eider, 2019a). He scored 48.80 in the qualifying run, and 48.87 in the finals. These achievements ensured his participation in the 32nd Olympic Games Tokyo 2020 (he did not compete in this running competition in Tokyo, however).

Marcin Lewandowski was a student of a 4.5-year full-time studies in Physical Education (major: Teaching) (Eider, Eider, 2015a), at the former Institute of Physical Culture of the Faculty of Natural Sciences of the University of Szczecin. He wrote his Master's thesis on 'Annual preparation cycle of Marcin Lewandowski for the 800 m run', which he defended on October 17, 2011 at the Faculty of Physical Culture and Health Promotion at the University of Szczecin (Table 1). The supervisor of Lewandowski's thesis was also the author of this publication (Eider, Eider, 2017).

Currently, he is a member of AZS UMCS Lublin and represents the world level in $800 \mathrm{~m}$ and 1,500 $\mathrm{m}$ athletics running competitions. He participated four times in the biggest sports competition in the world - the Olympic Games. He made his debut in 2008 in Beijing, followed by London (2012), Rio de Janeiro (2016), and most recently Tokyo 2020 (which took place in 2021). During the previous Olympic Games, he competed in the $800 \mathrm{~m}$ run, while in Tokyo he took part in the 1,500 m run. He secured his qualifying standard for the 32nd Olympic Games Tokyo 2020 during, inter allia, the Diamond League in Paris (August 24, 2019), where he set the Polish record in the 1,500 m run at 3:31.95. The PZLA standard was 3:35.00 (Lewandowski, 2021).

In 2015, Adam Nowicki graduated with a Bachelor's degree in Physical Education from the Faculty of Medicine and Health Sciences at the University of Zielona Góra. Currently, he is a part-time Master's student (1st year) in the field of Physical Education at the Faculty of Health and Physical Culture at the University of Szczecin. He prepares materials for his Master's thesis on his Olympic discipline - marathon, which he writes under the supervision of professor PhD Leonard Nowak.

Since 2013, he has been a member of MKL Szczecin, as well as a professional soldier in one of the Command Battalions in Szczecin. He does long-distance running (10,000 m, half-marathon, marathon). He achieved the qualifying standard for the Olympic Games Tokyo 2020 during the NN Mission Marathon in Enschede, Netherlands (April 18, 2021), in which he set a life record with a time of 2:10.21 (PZLA requirement: 2:11.30). This is the seventh best result achieved in the history of the Polish marathon so far. On the last day of the 32nd Olympic Games Tokyo 2020 (August 8, 2021), Adam Nowicki took 38th place in the men's marathon (the highest rank among Poles). After two weeks, one of the marathon runners was disqualified for doping, which gave Nowicki 37th rank - the best result among Polish runners (Nowicki, 2021b).

Jacek Kostrzeba was a student of 4-year full-time studies in Physical Education at the Institute of Physical Culture, University of Szczecin. The institute operated as faculty until September 30, 1992. His Master's thesis on 'Athletes' maximum oxygen consumption depending on age and sport preparation in medium distance competitions' was supervised by professor PhD Zbigniew Jethon. He passed his diploma examination in 1990 (Eider, 2019b).

$\mathrm{He}$ is an athletics coach who trains female and male athletes in middle-distance and endurance runs in UKS Barnim Goleniów, the national team and the Olympic team. He was part of the coaching staff at the 31st 
Olympic Games in w Rio de Janeiro (2016). He worked as a coach in the Polish Olympic team of endurance runners. His trainee, Krystian Zalewski (a student of WKFiPZ at the University of Szczecin) competed in the 3,000 m steeplechase, and was ranked 27 th.

Marcin Kolbowicz was a student of a 5-year full-time studies in Physical Education at the Institute of Physical Culture of the Faculty of Natural Sciences of the University of Szczecin. His Master's thesis on 'The analysis of the development of leading features in rowing in the Olympic cycle 1992-1996 on the basis of the preparation program of the $4 \mathrm{x}^{\prime}$ was supervised by prof. PhD Jan Jaszczanin. He passed his diploma examination in 1998. Currently, he works at the Institute of Physical Culture Sciences at the Faculty of Health and Physical Culture of the University of Szczecin. On June 26, 2012, the Council of the Faculty of Physical Education, Sport and Rehabilitation of the University of Physical Education in Poznań awarded Marek Kolbowicz with a doctoral degree in Physical Culture Sciences for his doctoral dissertation on 'The effectiveness of special physical preparation in the long-term process of sports training for Olympic rowers' (Eider, Eider, 2017). The doctoral dissertation was supervised by the author of this article. Marek Kolbowicz was an outstanding athlete who specialized in rowing. He practiced this Olympic discipline in 1986-2013. He won medals at major sports events, such as Olympic Games, World Championships, European Championships, and Polish Championships.

The analyzed research material was obtained through the author's and co-author's studies to date, the works of other authors, oral and written reports of athletes, the coach, expert, websites, biographical databases of athletes (data accessed on August 31, 2021).

\section{Results}

The Olympic competition in athletics (except for the marathon and racewalking) was held at the Olympic (national) stadium on July 30 - August 8, 2021. This stadium was the venue for the opening and closing ceremony of the 32nd Olympic Games Tokyo 2020. Patryk Dobek and Marcin Lewandowski competed in that beautiful sports facility, while the marathon runner Adam Nowicki competed on the streets of Sapporo (where marathon and racewalk took place).

The qualifiers for men's $800 \mathrm{~m}$ run took place on July 31, 2021. 48 players participated in six series - the top three competitors in each series qualified for the semi-finals, as well as six others with the best times. Patryk Dobek started in the 5th series, in which he was ranked 3rd with a time of 1:46.59. Another Polish representative, Mateusz Borkowski, came 2nd in the 6th series, with a time of 1:45.34. Both Poles advanced to the semi-finals, which took place on August 1, 2021 - in three series of 8 athletes. The top two competitors in each series and the other two with the best times in all three series advanced to the finals. Patryk Dobek competed in the first series, in which he was ranked 1st, with a time of 1:44.60, defeating an outstanding Kenyan athlete, Emmanuel Kipkurui Korir - a future gold medalist (Table 2). Unfortunately, in the second series, Mateusz Borkowski took the last place, and therefore did not advance to the finals. On August 4, 2021 nine runners took part in the finals; the winner was the aforementioned Kenyan athlete, Emmanuel Kipkurui Korir (1:45.06), while the second place was taken by his countryman, Rotich Ferguson Cheruiyot (1:45.23) (Table 2). Our titled runner secured a sensational bronze medal (1:45.39). He is the fourth Polish athlete who has competed in the finals of the $800 \mathrm{~m}$ Olympic run so far (thus he joined Paweł Czapiewski, Adam Kszczot, and Marcin Lewandowski), but he became first Polish Olympic medalist in this particular discipline. 
It should be emphasized that during championships events (such as the Olympics, World and European Championships), athletes compete primarily for medals, and not for record times. The Tokyo final run was quite slow, and the times achieved by the finalists significantly deviated from the world and Olympic records of Kenyan Radish Dawid Lekut (1:40.91) (www.olympices.com; Dobek, 2021).

Table 2. Participation in the Olympic Games Tokyo 2020

\begin{tabular}{|c|c|c|c|c|c|c|c|}
\hline \multirow{2}{*}{ First and last name } & \multirow{2}{*}{ Discipline - competition } & \multirow{2}{*}{$\begin{array}{l}\text { Score } \\
\text { (time) }\end{array}$} & \multirow{2}{*}{ Rank } & \multicolumn{4}{|c|}{ Medalists } \\
\hline & & & & medal & first and last name & country & score (time) \\
\hline & & & & Gold & Kipkarui Emmanuel Korir & Kenya & 1:45.06 \\
\hline \multirow[t]{3}{*}{ Patryk Dobek } & ATH $-800 \mathrm{~m}$ & $1: 45.39$ & $3 r d$ & Silver & Cheruigot Ferguson Rotich & Kenya & $1: 45.23$ \\
\hline & & & & Bronze & Patryk Dobek & Poland & $1: 45.39$ \\
\hline & & & & Gold & Jakob Ingebrigtsen & Norway & $3: 28.32$ \\
\hline \multirow[t]{3}{*}{ Marcin Lewandowski } & ATH $-1,500 m$ & $x$ & $x$ & Silver & Timothy Cheruigot & Kenya & 3:29.01 \\
\hline & & & & Bronze & Josh Kerr & England & 3:29.05 \\
\hline & & & & Gold & Eliud Kipchoge & Kenya & $2: 08.38$ \\
\hline \multirow[t]{2}{*}{ Adam Nowicki } & ATH - marathon & $2: 17.19$ & 37 th & Silver & Abdi Nageeye & The Netherlands & $2: 09.58$ \\
\hline & & & & Bronze & Bashir Abdi & Belgium & $2: 10.00$ \\
\hline
\end{tabular}

$x$ - interrupted the semi-final race due to a calf injury.

Source: Dobek (2021); Lewandowski (2021); Nowicki (2021b); www.olympices.com.

In 2021, Patryk Dobek started to compete in the $800 \mathrm{~m}$ run with great success - he obtained very good time results at competitions of various ranks (he won medals and achieved the qualifying standard for the Tokyo Olympics). In February, in Torun's 65th Polish Indoor Athletics Championships, Patryk Dobek won the Polish Championships in the $800 \mathrm{~m}$ run with a time of 1:47.12, defeating, among others, a titled runner Adam Kszczot. In the same city, in March, the 36th European Athletics Indoor Championships took place. In his newly trained running competition - 800 m run - Dobek won a sensational gold medal, with a time of 1:46.81 (woj., 2021a). At the June athletics meeting held in Montreuil, France, he won the $800 \mathrm{~m}$ run with a very good time (1:44.76), and obtained the qualifying standard set by the Polish Athletic Association (1:45.20) for the 32nd Olympic Games Tokyo 2020. He achieved an even better result in Chorzów, during the 67th Janusz Kusociński Memorial - which was also held in June (June 20, 2021). He won with a time of 1:43.73, setting a new personal record, as well as the world record at that time (woj., 2021b). In June (June 26, 2021) he also participated in the 97th PZLA Polish Championships in Poznań, where he won the Polish championship in the $800 \mathrm{~m}$ run with a time of 1:48.21. He competed in the 32nd Olympic Games Tokyo 2020 only in the $800 \mathrm{~m}$ run and won unexpectedly a bronze medal with a time of 1:45.39 as a member of the Municipal Athletics Club (MKL) Szczecin.

A graduate of the University of Szczecin, Marcin Lewandowski, competed during the Tokyo 2020 Olympics in the 1,500 m run together with another Polish representative, Michał Rozmys (Przegląd Sportowy, 2021). Three qualifier runs (16-person each) took place on August 3, 2021. Michał Rozmys started in the first race and took the 6th place with a time of 3:36.28; thus, he advanced to the semi-finals (the top six runners advanced to the semi-finals from each qualifying race). Marcin Lewandowski participated in the second race, during which he fell (due to another competitor's fault), but ended this unfortunate race in the last place, with a time of 4:43.96. The protest submitted by the PZLA authorities was accepted and thus our representative found himself among the semi-finalists. 
Two semi-final races ( 13 competitors each) took place on August 5, 2021. The first one was attended by Marcin Lewandowski; unfortunately, during the run, his injury of the left leg - which had not been completely healed - flared up. He was forced to leave the track; he did not finish the race and thus was disqualified. Jake Wightman from Great Britain won the race, with a time of 3:33.48. Michał Rozmys took part in the second semi-final race. He finished in last place - in one shoe (during the run one of the competitors stepped onto his shoe, which slipped off some time after). After the race was over, the judges positively responded to the protest submitted by the PZLA authorities, and as a result he was included into the final race (Kostrzeba; 2021; Lewandowski, 2021; www.olympices.com).

The final race (with 13 competitors) took place on August 7, 2021. The winner was an exceptional Norwegian runner, Jakob Ingebrigtsen, who ran 1,500 m in 3:28.32 (Table 2). Our finalist took the 8th place with a time of 3:32.67 - his new personal best. Marcin Lewandowski, who was in good health, without any injuries, and in a good preOlympic shape (on July 9, 2021, he set a Polish record - 3:30.42) could have fought for the coveted Olympic medal. Unfortunately, for health reasons, his fourth participation in the Olympics turned out to be unsuccessful.

In 2021 (the year of the postponed Olympics), he set other Polish records: indoors (3:35.71), at the Copernicus Cup meeting in Torun (February 17, 2021) and at the stadium (3:30.42) during the Diamond League in Monaco (July 9, 2021). So far in his Olympic career, he was ranked 6th in the final race at the 31st Olympic Games in Rio de Janeiro (2016).

Marcin Lewandowski has won numerous medals, such as: World Championships (at the stadium), Indoor World Championship, the European Championships (at the stadium), the European Indoor Championships, the Super League of the European Team Championships, the World Military Sports Games, the European Military Championships, the Youth European Championships, IAAF World Relays, Polish Championships (juniors, youth, seniors) (Bała, 2019, 2021; Eider, Eider, 2015a, 2015b, 2017; Eider, 2020a, 2020b; Lewandowski, 2021; www. wikipedia.pl; Przegląd Sportowy, 2021).

So far, his greatest medal achievement is probably the bronze medal for the 1,500 m run (October 6, 2019) won at the 17th World Championships in Doha (Qatar) - "... the athlete calmly passed through the qualifying rounds and the semi-final, only to explode in the finals. On the final stretch he chased two front-runners, and did not surrender his 3rd rank to a couple of other competitors. He also secured an excellent time result for Poland - 3:31.46' (Bała, 2019, p. 14). Earlier - in 2018, at the World Indoor Championships in Birmingham, he also won a silver medal in the $1,500 \mathrm{~m}$ run. He is an eight-time medalist of the European Championships at the stadium and indoors in middle-distance running: 800 m, 1,500 m (www.wikipedia.pl).

Marcin Lewandowski is a titled athlete, who proudly represents Poland at the largest sports events in athletics. For his sports achievements he was decorated with the Knight's Cross of the Order of Polonia Restituta and the Golden Cross of Merit (Lewandowski, 2021).

WKFiZ US student, Adam Nowicki competed in the marathon (42.195 km), which took place on August 8, 2021 in Sapporo Odori Park, in the morning, at a temperature of $25-26^{\circ} \mathrm{C}$ and nearly $70 \%$ air humidity (Nowicki, $2021 \mathrm{~b}$ ). 106 competitors participated in that race - and only 76 completed it. The winner was Kenyan Eliud Kipchoge, with a time of 2:08.38. Among the three Polish marathon runners (Marcin Chabowski, Arkadiusz Gardzielewski, Adam Nowicki), Adam Nowicki turned out to be the best; he finished the Tokyo marathon in 2:17.19, taking the 38th place. When one of his competitors was disqualified for doping, our runner ended up at the 37th place (Nowicki, 2021b), while Arkadiusz Gardzielewski was ranked 63rd (2:22.50). Unfortunately, Marcin Chabowski was among the 30 competitors who withdrew from that very difficult marathon run (www.olympics.com). 
In his sports career to date, Adam Nowicki has won five medals at the Polish Seniors Championships in the 10,000 m run - three silver medals (Postomin 2014, Białogard 2016, Rybnik 2017), and two bronze medals (Wieliczka 2015, Karpacz 2020). In the half-marathon, he won three medals: two gold ones (Piła 2014, Bydgoszcz 2020) and one silver (Piła 2018) (Nowicki, 2021a, 2021b; www.wikipedia.pl). In 2017, he took up the marathon, dreaming of competing in the Tokyo 2020 Olympics. He made his debut in 2018 in the Warsaw Marathon, and took the 3rd place with a time of 2:17.28 - he was the best Polish competitor in that event (Nowicki, 2021b; Przeglaqd Sportowy, 2021). At the Polish Championships, he won two medals: a silver one (Olesno 2020) and a bronze one (Warsaw 2019).

Apart from the two students of the University of Szczecin - Patryk Dobek and Adam Nowicki - and a graduate, Marcin Lewandowski, the Polish Olympic team included a graduate of our university, Jacek Kostrzeba in the coaching staff. Michał Rozmys, his club and staff runner successfully competed in Tokyo 2020; he took 8th place in the final 1,500 m, improving his life record. His trainee, Angelika Mach from AZS UMCS Lublin, also participated in the Tokyo marathon (August 7, 2021). She was among 73 competitors, and ultimately took 59th place; she finished the race in very difficult weather conditions (Kostrzeba, 2021). As a coach, Kostrzeba cooperated with other trainers who took care of Polish competitors of the Tokyo marathon.

His trainees won many medals at the Polish Championships, for example Krystian Zalewski won gold medals in the $3,000 \mathrm{~m}$ steeplechase, 5,000 m and 10,000 m run at the 95th PZLA Polish Championships in Radom (August 23-25, 2019). Zalewski, once the 2019 athletics season ended, and he summarized his sports achievements todate, analyzed his running predispositions, and had professional conversations with his coach Jacek Kostrzeba, decided to prepare for the marathon and obtain the qualifying standard (PZLA requirement 2:11.30) which would guarantee his participation in the Tokyo Olympics (Zalewski, 2020). In 2021 (April 18, 2021) he competed in Dębno in the 91st PZLA Polish Marathon Championships. All three medalists of that championships: Arkadiusz Gardzielewski (2:10.31), Kamil Karbowiak (2:10.35), and Krystian Zalewski (2:10.58) ran the marathon in a shorter time than the PZLA standard (which was 2:11.30). In the previously mentioned Enschede marathon, better times were achieved by Marcin Chabowski (2:10.17), and Adam Nowicki (2:10.21). Of the five marathon runners mentioned, only three with the best times represented Poland at the 32nd Olympic Games in Tokyo - without Zalewski. In Dębno on April 18th, 2021, Angelika Mach, an athlete trained by Jacek Kostrzeba, took part in the 41st PZLA Polish Championships in Women's Marathon. She took 2nd place with a time of 2:27.48, which allowed her to participate in marathon run at the Olympic Games Tokyo 2020 (Kostrzeba, 2021).

Among the Olympians trained by the coach Jacek Kostrzeba, there is also a UKS Barnim Goleniów member (since 2015), Michał Rozmys - a professional soldier of the Polish Army. He is a repeated Polish representative in middle-distance running $(800 \mathrm{~m}$ and $1,500 \mathrm{~m}$ ). The coach from Goleniów significantly influenced the sports progress of this athlete, who in 2019 won the gold medal in the $1,500 \mathrm{~m}$ run at the Universiade in Naples. In the same year, he competed in the World Military Sports Games in Wuhan, where he won two gold medals: in the $800 \mathrm{~m}$ and 1,500 m run. He also won the gold medal in the 1,500 $\mathrm{m}$ run at the Polish Indoor Championships held in Torun (February 16-17, 2019). He secured his qualifying standard for the 32nd Olympic Games Tokyo 2020 on June 9, 2021 during athletics meeting in Marseille. He completed the 1,500 m run in 3:34.96 (PZLA requirement was 3:35.00), which was his new personal record, and guaranteed participation in the Tokyo Olympics (Kostrzeba, 2021; www.pzla.pl; www.wikipedia.pl). 
The titled rower, Marek Kolbowicz, PhD, an employee of the Institute of Physical Culture Sciences at the University of Szczecin, upon completing his sports career became an expert in rowing at the largest sports events (e.g. World and Europe Championships). He was in the 15-strong team of the Polish Olympic television 'TVP' (Urbaś, 2021; Tymiński, 2021) which broadcast sports competitions in Tokyo 2020, mainly in disciplines with the participation of Polish representatives. Dariusz Szpakowski, a long-time excellent sports journalist, was the commentator for rowing (and canoeing), while the expert was the Olympic champion of $4 \times$ in Beijing (2008) Marek Kolbowicz (Kolbowicz, 2021).

Marek Kolbowicz was an outstanding athlete specialized in rowing; he practiced this Olympic discipline in 1986-2013. He won medals at major sports events, such as Olympic Games, World Championships, European Championships, and Polish Championships. He is the Olympic champion (along with Michał Jeliński, Adam Korol, Konrad Wasielewski - a graduate of IKF WNP US) in 4x rowing in Beijing (2008), four-time world champion (Gifu 2005, Eton 2006, Munich 2007, Poznań 2009), European champion (Monte-o-Velho 2010), multiple Polish champion, and a five-time participant of the Olympic Games (Atlanta 1996, Sydney 2000, Athens 2004, Beijing 2008, London 2012) (Eider, Eider, 2015b, 2017; Eider, 2020b; Kolbowicz, 2021; Piechal et al., 2019). His numerous sports achievements have been described in detail in many studies (e.g. Eider, Eider, 2015a, 2015b, 2017), and the President of Poland, Bronisław Komorowski, awarded him with the title of the Athlete of the First Decade of the 21st Century (Urbaś, 2011).

\section{Discussion}

For the first time in the history of the Summer Olympics, the International Olympic Committee has postponed the event to the following year. The largest quadrennial sports competition took place in the odd year, between July 23 and August 8, 2021, without the participation of spectators. This decision was made due to the spreading SARSCoV-2 pandemic. As it turned out later, it was the right decision, which prevented numerous infections, deaths among the local population, as well as the organizers and participants of the Tokyo Olympics. However, postponing such a large event to the following year, maintaining the sports facilities, the Olympic village, etc., significantly increased the costs of its organization (Banio 2021b, Jastrząbek, 2021; Urbaś, 2021). A survey conducted among numerous athletes showed their positive attitude to the decision to reschedule the Games to 2021 (Banio, 2021c).

The Olympic Games Tokyo 2020 (the name Tokyo 2020 was retained by the decision of the IOC) were conducted under strict sanitary restrictions, so as not to increase the number of COVID-19 infections.

There were three athletes in the Polish Olympic team participating in the Tokyo competition associated with the University of Szczecin (US), the largest university in the Western Pomerania region. Two of them, Patryk Dobek and Adam Nowicki, are current students of the Faculty of Physical Culture and Health of the US, who skillfully combine competitive sports with education, while Marcin Lewandowski is a graduate of the Faculty of Physical Culture and Health Promotion of the US (Documentation, 2021).

Polish athletes won 14 medals at the Tokyo Olympics, including 4 gold ones, 5 silver ones, and 5 bronze ones - which is the best result so far in the 21 st century. Among the medalists is Patryk Dobek, who unexpectedly won a bronze medal in the $800 \mathrm{~m}$ run. This was the first Olympic medal won by a Pole, as well as a European, at this distance since 2004. His results during the most important athletics competitions, medals he won and the results he obtained in 2021 indicated that he could become a great surprise at the Olympics. The tactics of rather slow final run, which he developed with his coach, Zbigniew Król, proved to be very successful. 
The other US student, Adam Nowicki, performed well in the marathon run. He was among 76 runners who finished the marathon, and took the 37th place (as many as 30 participants withdrew and did not reach the finish line). Atmospheric conditions (high temperature, high humidity) were the main factors that negatively affected the runners who decided not to finish the marathon. It should be noted that Adam Nowicki was included in the central training program only a few months before his Tokyo start (Nowicki, 2021b). Lack of participation in previous training camps abroad (acclimatization) probably had a significant impact on his sports level in his debut marathon run.

Marcin Lewandowski had a very unsuccessful start at the Olympic Games in the 1,500 m run. He fell down in the qualifying run, and his leg injury flared up in the finals. In 2021, before Tokyo 2020, he participated in several athletic events, where he demonstrated a high sports level (including a new life record of 3:30.42). Many years of track and field experience and his results in the 1,500 $\mathrm{m}$ run indicated that he stood a good chance of competing in the Olympic finals and fighting for a medal. However, at the Tokyo Olympics, he was not able to fulfill his dream of being among the medalists.

Perhaps at the 33rd Olympic Games in Paris (2024 - potentially his fifth Olympics - he will win an Olympic medal?

Not only athletes participate in the Olympic Games - other participants include coaches, judges, association authorities and activists, doctors, physiotherapists, psychologists, and media representatives. In Tokyo, the coaching staff included Jacek Kostrzeba, a graduate of the Institute of Physical Culture at the University of Szczecin, who trained many athletes in middle-distance and endurance running. One of his trainees is Michał Rozmys - finalist in the 1,500 m run. Media representatives included Marek Kolbowicz PhD, a graduate of the Institute of Physical Culture at the Faculty of Life Sciences of the University of Warsaw, who acted as an expert in rowing and canoeing (Kolbowicz, 2021). He is a titled gold medalist in $4 \times$ rowing (Olympic champion, four-time world champion, European champion, and multiple Polish champion in various competitions). As an academic teacher, he has great knowledge of rowing, sports theory, and nutrition. He used his professional and training-related expertise during TV broadcasts from Tokyo of rowing competitions.

Other outstanding athletes also played the role of experts in their respective Olympic disciplines in Tokyo (e.g. Otylia Jędrzejczak, Sebastian Chmara). It was very fortunate that the authorities of Eurosport and TVP selected titled sportsmen for the commentators; they enriched the broadcast with their expert knowledge (Urbaś, 2021; Tymiński, 2021).

\section{Conclusions}

1. The 32nd Olympic Games Tokyo 2020 were held in 2021 due to the spreading pandemic of COVID-19.

2. The Polish Olympic team who participated in the Tokyo 2020 Games included three athletes (runners) associated with the University of Szczecin: Patryk Dobek - 800 m run, Marcin Lewandowski - 1,500 m run, and Adam Nowicki - marathon.

3. The coaching staff of Polish athletes included another graduate of the University of Szczecin, Jacek Kostrzeba.

4. Marek Kolbowicz, PhD - an employee of the Institute of Physical Culture Sciences at the Faculty of Health and Physical Culture of the University of Szczecin (INoKF WKFiZ US), acted as a TV commentator/rowing expert.

5. WKFiZ US' student - Patryk Dobek - won a bronze medal in the $800 \mathrm{~m}$ run, which was an unexpected surprise in the Polish Olympic team. 


\section{Bihliography}

\section{Archives}

Archival documentation of Student Support Department, Student Affairs Section (2021), Faculty of Physical Culture and Health, University of Szczecin.

\section{Monographs and articles}

Eider, J., Eider P. (2015a). Olimpijczycy - absolwenci Wyższej Szkoły Pedagogicznej w Szczecinie, Uniwersytetu Szczecińskiego, kierunku studiów wychowanie fizyczne. In: J. Eider (ed), Wybrane zagadnienia olimpijskie w teorii i praktyce (pp. 121-136). Szczecin: Wydawnictwo Naukowe Uniwersytetu Szczecińskiego.

Eider, J., Eider, P. (2015b). Olimpijczycy szczecińskich klubów sportowych na igrzyskach XXVIII-XXX Olimpiady Ateny-Pekin-Londyn. In: J. Eider (ed.), Ruch olimpijski w teorii i praktyce (pp. 83-96). Szczecin: Wydawnictwo Naukowe Uniwersytetu Szczecińskiego.

Eider, J. Eider, P. (2017). Problematyka olimpijska i paraolimpijska w działalności Wydziału Kultury Fizycznej i Promocji Zdrowia Uniwersytetu Szczecińskiego. Szczecin: Wydawnictwo Naukowe Uniwersytetu Szczecińskiego.

Eider, J. (2019a). Gradutes of the University of Szczecin in the group of trainers who stand as a candidate for the polish representation of the 32nd Olympics or the 16th Tokyo Paralympics 2020. Central European Journal of Sport Sciences and Medicine, 3, 65-73.

Eider, J. (2019b). Students of the University of Szczecin as candidates for the Olympic or Paralympic Games Tokyo 2020. Central European Journal of Sport Sciences and Medicine, 2, 67-76.

Eider, J. (2020a). Tokyo 2020 Olympic and Paralympic qualifications obtained by students, graduates and of the Szczecin University. Central European Journal of Sport Sciences and Medicine, 4, 77-84.

Eider, J. (2020b). Wydziałowa Sala Osiągnięć Sportowych w Uniwersytecie Szczecińskim. Szczecin: Wydawnictwo Naukowe Uniwersytetu Szczecińskiego.

Bała, R. (2019), Przedolimpijski Katar wyleczony. Magazyn Olimpijski, 3 (128), 12-14.

Bała, R. (2021). Strzał w „dziesiątkę". Magazyn Olimpijski, 1 (134), 24-27.

Banio, A. (ed.) (2021a). Letnie Igrzyska Olimpijskie Tokyo 2020 w obliczu pandemii COVID-19. Szczecin: Wydawnictwo Naukowe Uniwersytetu Szczecińskiego.

Banio, A. (2021b). Od redaktora. In: A. Banio (ed), Letnie Igrzyska Olimpijskie Tokyo 2020 w obliczu pandemii COVID-19 (pp. 7-21). Szczecin: Wydawnictwo Naukowe Uniwersytetu Szczecińskiego.

Banio, A. (2021c). Sytuacja sportowców wobec decyzji MKOL o przesunięciu terminów igrzysk olimpijskich. In: A. Banio (ed.). Letnie Igrzyska Olimpijskie Tokyo 2020 w obliczu pandemii COVID-19 (pp. 93-111). Szczecin: Wydawnictwo Naukowe Uniwersytetu Szczecińskiego.

Jastrząbek, J. (2021). Ekonomiczne skutki przełożenia igrzysk olimpijskich. In: A. Banio (ed), Letnie Igrzyska Olimpijskie Tokyo 2020 w obliczu pandemii COVID-19 (pp. 47-1). Szczecin: Wydawnictwo Naukowe Uniwersytetu Szczecińskiego.

Omorczyk, A. (2021). Szanse, zagrożenia i możliwe implikacje dla miasta, jego przestrzeni oraz mieszkańców na skutek zmiany daty igrzysk olimpijskich. In: A. Banio (ed), Letnie Igrzyska Olimpijskie Tokyo 2020 w obliczu pandemii COVID-19 (pp. 73-91). Szczecin: Wydawnictwo Naukowe Uniwersytetu Szczecińskiego.

Piechal, T., Urbaś, H.,Wolfke, T., Jakobsche, J., Sikora, Z., Rawa, K., Cymerman, A. (eds.) (2019). 100 lat na olimpijskim szlaku. Warszawa: Polski Komitet Olimpijski.

Przegląd Sportowy (2021). Reprezentacja Polski. Skarb Kibica Igrzyska Olimpijskie Tokio 2020. Dodatek do Przeglądu Sportowego, 22 lipca, 54-77.

Rozmiarek M. (2021). W pogoni za olimpijskim marzeniem Shinzo Abe? Igrzyska w polityce Japonii w 2020 roku. In: A. Banio (ed.), Letnie Igrzyska Olimpijskie Tokyo 2020 w obliczu pandemii COVID-19 (pp. 23-46). Szczecin: Wydawnictwo Naukowe Uniwersytetu Szczecińskiego.

Tymiński R. (2021). Dylemat telewizyjny i internetowy. Skarb Kibica Igrzyska Olimpijskie Tokio 2020. Dodatek do Przeglądu Sportowego, 22 lipca, 52-53.

Urbaś, H. (2011). Złota Galeria. Magazyn Olimpijski, 3 (124), 36-37.

Urbaś, H. (2020). Czas niepewności. Magazyn Olimpijski, 1 (130), 3.

Urbaś, H. (2021). Inne niż wszystkie. Magazyn Olimpijski, 1 (34), 4-5. 


\section{Daily press}

woj. (2021a). Patryk Dobek sensacyjnym mistrzem Europy. Kurier Szczeciński, 9 marca, 15.

woj. (2021b). Trzecia życiówka od początku czerwca. Kurier Szczeciński, 22 czerwca, 15.

\section{Written accounts}

Nowicki Adam, 2021a

\section{Oral accounts}

Dobek Patryk, 2021.

Kolbowicz Marek, 2021.

Kostrzeba Jacek, 2021.

Lewandowski Marcin, 2021.

Nowicki Adam, 2021b

\section{Internet sources}

www.olimpijski.pl.

www.olympics.com.

www.pzla.pl.

www.wikipedia.pl.

Cite this article as: Eider, J. (2021). Students and Graduates of the University of Szczecin at the 32nd Olympic Games Tokyo 2020. Central European Journal of Sport Sciences and Medicine, 3 (35), 5-15. DOI: 10.18276/cej.2021.3-01. 